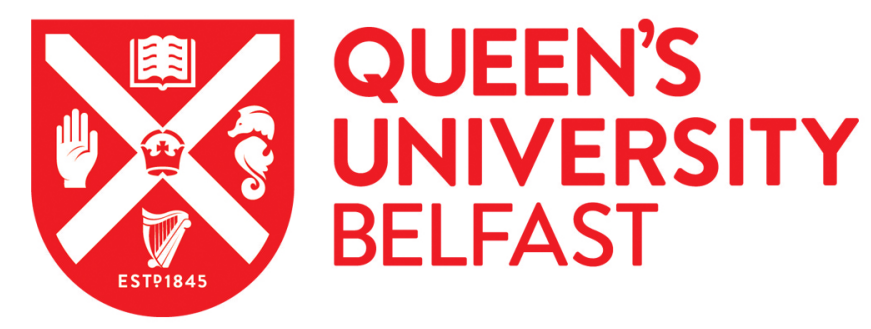

\title{
The application of the ecological footprint in two Irish urban areas: Limerick and Belfast
}

Walsh, C., McClone, A., O'Regan, B., Moles, R., \& Curry, R. (2006). The application of the ecological footprint in two Irish urban areas: Limerick and Belfast. Irish Geography, 39(1), 1-21.

\section{Published in:}

Irish Geography

Document Version:

Publisher's PDF, also known as Version of record

Queen's University Belfast - Research Portal:

Link to publication record in Queen's University Belfast Research Portal

\section{General rights}

Copyright for the publications made accessible via the Queen's University Belfast Research Portal is retained by the author(s) and / or other copyright owners and it is a condition of accessing these publications that users recognise and abide by the legal requirements associated with these rights.

Take down policy

The Research Portal is Queen's institutional repository that provides access to Queen's research output. Every effort has been made to ensure that content in the Research Portal does not infringe any person's rights, or applicable UK laws. If you discover content in the Research Portal that you believe breaches copyright or violates any law, please contact openaccess@qub.ac.uk. 
This article was downloaded by: [The Library at Queens]

On: 11 November 2011, At: 02:27

Publisher: Routledge

Informa Ltd Registered in England and Wales Registered Number: 1072954 Registered office: Mortimer House, 37-41 Mortimer Street, London W1T 3J H, UK

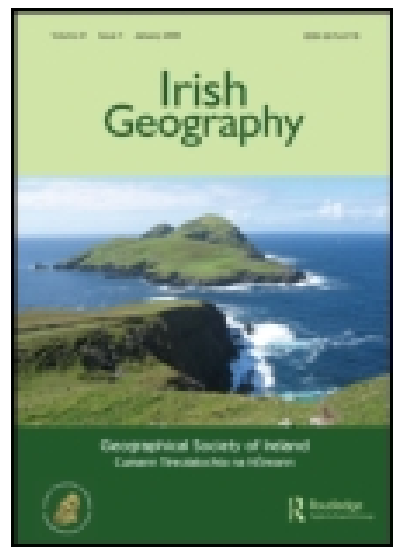

\title{
Irish Geography
}

Publication details, including instructions for authors and subscription information: http:// www. tandfonline.com/loi/ rigy20

\section{The application of the ecological footprint in two Irish urban areas: Limerick and Belfast}

\author{
Conor Walsh ${ }^{a}$, Annabel McLoone ${ }^{a}$, Bernadette O'Regan ${ }^{a}$, Richard Moles ${ }^{a} \&$ Robin Curry ${ }^{b}$ \\ ${ }^{a}$ Centre for Environmental Research, Chemical and Environmental Sciences Department, \\ University of Limerick, Ireland \\ ${ }^{\mathrm{b}}$ EnviroCentre, 27 College Gardens, Belfast, BT9 6BS
}

Available online: $26 \mathrm{~J}$ an 2010

To cite this article: Conor Walsh, Annabel McLoone, Bernadette O'Regan, Richard Moles \& Robin Curry (2006): The application of the ecological footprint in two Irish urban areas: Limerick and Belfast, Irish Geography, 39:1, 1-21

To link to this article: http:// dx. doi.org/ 10.1080/00750770609555863

\section{PLEASE SCROLL DOWN FOR ARTICLE}

Full terms and conditions of use: http://www.tandfonline.com/page/terms-and-conditions

This article may be used for research, teaching, and private study purposes. Any substantial or systematic reproduction, redistribution, reselling, loan, sub-licensing, systematic supply, or distribution in any form to anyone is expressly forbidden.

The publisher does not give any warranty express or implied or make any representation that the contents will be complete or accurate or up to date. The accuracy of any instructions, formulae, and drug doses should be independently verified with primary sources. The publisher shall not be liable for any loss, actions, claims, proceedings, demand, or costs or damages whatsoever or howsoever caused arising directly or indirectly in connection with or arising out of the use of this material. 


\title{
The application of the Ecological Footprint in two Irish urban areas: Limerick and Belfast
}

\section{Conor Walsh'1, Annabel McLoone1, Bernadette O'Regan1, Richard Moles $^{1}$ and Robin Curry ${ }^{2}$}

\author{
${ }^{1}$ Centre for Environmental Research, Chemical and Environmental Sciences Department, \\ University of Limerick, Ireland \\ ${ }^{2}$ EnviroCentre, 27 College Gardens, Belfast BT9 6BS
}

\begin{abstract}
The ecological footprint is now a widely accepted indicator of sustainable development. Footprinting translates resource consumption into the land area required to sustain it, and allows for an average per capita footprint for a region or nation to be compared with the global average. This paper reports on a project in which footprints were calculated for two Irish cities, namely Belfast in Northem Ireland and Limerick in the Republic of Ireland for the year 2001. As is frequently the case at sub-national scale, data quality and availability were often problematic, and in general data gaps were filled by means of population proxies or national averages. A range of methods was applied to convert resource flows to land areas. Both footprints suggest that the lifestyles of citizens of the cities use several times more land than their global share, as has been found for other cities.
\end{abstract}

Key index words: Ecological footprint, Ireland, cities.

\section{Introduction}

The publication of the Brundtland Commission's report entitled 'Our Common Future' in 1987 provided the most commonly used definition of sustainable development, as development which 'meets the needs of the present without compromising the ability of future generations to meet their own needs' (WCED, 1987:54). The strength of the concept of sustainable development is that it encompasses environmental, social and economic dimensions. However, this is also a weakness, as it is unclear what if anything falls outside its scope. For this reason it is felt that the concept has become corrupted, and has raised some doubts on the importance of sustainable development to policy and decision-making. If a concept can potentially mean anything then it effectively means nothing and becomes difficult to measure in a meaningful way. A concept that cannot be measured cannot be an effective management tool.

Scientists and professionals have taken (or been given) the impossible task of achieving definitive measurement of this word. The impossible task was to measure what was never potentially measurable: the immeasurable 'sustainability' (Bell and Morse, 1999:151).

In an attempt to overcome these difficulties, a number of indicators designed to measure sustainability have been developed. A prominent example is the genuine progress indicator (GPI), which removes the cost of crime, family breakdown and pollution from the gross

Irish Geography, Volume 39(1), 2006, 1-21. 
domestic product (GDP) figure. When applied in a time series, genuine progress is decreasing in many developed countries (Hamilton, 1999). In addition the GPI has also been applied to the rural communities of Nova Scotia, which demonstrates the increasing costs (in the form of income and expenditure ratios) required in operating small-scale farms (Lambert, 2005). Another indicator, material intensity per unit of service (MIPS) combines lifecycle analysis and material accounting, by attempting to quantify the materials and energy used throughout the entire production process, to provide an inclusive picture of resource use associated with industrial production (Schmidt-Bleek, 1994). It must be noted that there is no single perfect indicator; each member of the indicator toolbox has strengths and weaknesses. However, another indicator, the ecological footprint has gained wide recognition and application. Developed by Mathis Wackernagel and William Rees in the early 1990s, the ecological footprint is a resource accounting index that translates human resource demand to the land area required to produce the resources needed and sequester, or dispose of, wastes. Since then there has been much research undertaken to develop the footprinting methodology. This focus on resource consumption and land use is seen by many to be a successful amalgamation of the methodology and ideology of sustainable development since it is measured in relation to the tangible and everyday products and services provided by natural processes.

Indicator issues

Van den Berhg and Verbruggen (1999) provide a list of characteristics that an indicator of sustainability must satisfy in order to be effective. An indicator needs to be based on sound scientific methods. Any inherent assumptions must be verifiable and allow for new information to be incorporated into any indicator set. These indicators must be easily and logically connected to policy decisions. Unless the indicators themselves can be used to practical affect they will serve little purpose. This highlights the point that many of the criticisms of the footprint methodology are common to many indicators in general and specifically other sustainability indicators. One of the questions raised by some researchers concerns the merit of using an aggregate indicator. However, Van den Bergh and Verbruggen argue that any indicator of sustainability should represent as much of the whole system as possible. This may be taken as support for the adoption of the footprint as an indicator as it combines many sectoral indicators into a single index.

Victor (1994) suggests that adoption of aggregate indicators is based on the assumption of a high degree of substitution between natural and non-natural capital. If these differing forms of capital cannot be substituted then their aggregation cannot be justified and each indicator should be dealt with separately. This is of particular importance when evaluating indicators similar to the genuine progress indicators, due to the inherent difficulties in substituting an economic metric for ecosystem services. While ecosystem services have been valued at $\$ 33$ trillion globally (Constanza et al., 1997) it is certainly the case that human capital or endeavour could not replicate the services provided by, for example, the nitrogen cycle, through which the nitrogen required to sustain agriculture is made available through bacterial fixation of atmospheric nitrogen.

The non-substitutability of land has been claimed as one of the footprint's greatest strengths, however, land is not the only resource for which this claim might be made. McDonald and Patterson (2004) state that the same could be claimed for embodied (solar) energy stored in photosynthetic vegetation or any natural capital. However the nonsubstitutability of land means that the footprint acts as an indicator for strong sustainability. 
Only equally bio-productive land, or more precisely, bio-capacity can replace lost biocapacity substitute fully for the area appropriated by human resource consumption and waste assimilation.

Others argue against the adoption of aggregated indicators in policy making. The use of a single aggregate indicator, in this case a single land unit, is considered by some to be too abstract to inform policy change. Instead it has been suggested that looking at indicators individually, such as waste generation, can be better related to policy decisions. However there have been many examples of footprints calculated so as to provide information on individual components such as waste production. Further, calculation of a footprint necessarily requires bringing together of information from diverse institutions and government agencies, and this integrative process may be considered an essential step in facilitating sustainable development. Perhaps the greatest advantage of the footprint in terms of policy application is its ability to show up changes resulting from past policies, and hence likely changes resulting from future policies.

\section{City Footprinting}

Modern cities are increasingly recognised as motors of regional and national economies. However, increased technological advances are the result of increases in consumption levels. Cities act as intense centres of human consumption, appropriating the carrying capacity of much wider regions. This effectively expands a city's resource hinterland to include local, national and intemational bio productivity. 'In effect cities have become ... black holes drawing in energy and matter from all over the ecosphere' (Wackernagel and Rees, 1996a:237).

The resources provided by this hinterland may act as a stimulus for increased urban resource consumption, placing further environmental burdens on city hinterlands. These demands placed on the surrounding rural areas can also have the positive effect of such rural areas becoming economically viable. However this can come at the cost of uncontrolled urban expansion and degradation of local ecosystem services through increased deforestation, for example (McGranahan and Satterthwaite, 2003). One of the prerequisites of sustainable development is sustainable use of an urban region's hinterland. Urban areas often serve to depopulate the surrounding rural area (or alternatively suburbanise it); while at the same time rural bio-productivity is becoming ecologically more important as a source of resources and a waste sink.

\section{The evolution of the Footprint concept}

While not exclusively designed towards accounting for the consumption of countries, the original footprint concept as demonstrated in Wackernagel and Rees (1996) was best suited towards footprinting at a national level. The original model divided consumption into five main categories: food, housing, transportation, consumer goods, and services. These are quantified by trade corrected consumption data. Once sufficient information has been developed, the model can calculate a national footprint and scale it down to an approximate per capita figure. This method can be applied to any number of categories, for example, arable land to produce food, energy land to sequester the $\mathrm{CO}_{2}$ emissions from industry, transport, and so on through carbon capture in forest plantations, for example. Other footprint land use categories in the early model include: built land, currently used land and land of limited availability, such as old growth forests and non-productive areas. A national or regional 
ecological footprint can be compared to locally available bio-capacity. When expressed using global yields and averages, a per capita footprint can be compared to the 'global earth share'; the average global per capita land area, as a means of pointing up the finite nature of natural capital. However, it should be noted that this is a hypothetical land use model and do not represent actual land use. As an indicator of sustainable development, footprinting is seen as having both advantages (See Wackernagel and Rees, 1996) and disadvantages (See Van den Bergh and Verbruggen, 1999), summarised here in Table 1.

Table 1: Advantages and disadvantages of Footprinting.

Advantages of footprinting

Single unit indicator that allows disaggregation.

Widely applicable to activities

Top down or bottom up

Useful communication tool

Continually being updated

and improved

Demonstrates the finite nature of natural capital

Growing credibility as policy tool
Disadvantages of footprinting

Mostly hypothetical land uses

Can oversimplify resource use

Detailed studies incur uncertainty, particularly at sub-national level.

Double counting is always a risk

Mostly snapshots of consumption

Provides no clear policy guidance except to consume less or create additional productive land

Based on sometimes doubtful assumptions

Can be difficult to reconcile annual consumption with the necessarily much slower provision of bio-capacity

More recent work, for example by Erb (2004), has sought to downplay these disadvantages. To summarise, footprinting challenges the view that sustainable development is not quantifiable, and may allow for the practical application of the sustainability precept 'think globally and act locally'.

The ecological footprint has the ability to transform sustainability from a vague concept into a measurable goal. It is a global budgeting approach dividing the planet into available ecological space per capita (Deutsch, 2000:351).

\section{A more complete model}

While the original method was transparent and therefore robust, it was criticised by Van den Bergh and Verbruggen (1999) and others, for being too simple and confined to national footprinting, which resulted in regional variations being overlooked. The original method has been described as compound footprinting, since many consumption categories are in an aggregated form and national trade data are used in calculations. Organisations and regions were accounted for by proxies applied to national data: hence compound footprinting has been defined as a top-down method. A more recent method, developed by the UK consultancy 
BestFootForward (specialising in footprinting) is described as a component approach, as consumption categories are broken down into their respective components. Thus, for example instead of accounting for hardwood and softwood flows through national trade data, component footprinting attempts to account for consumption in terms of the products that comprise these categories, such as furniture and building materials. This also allows for activities such as car travel to be included within a footprint calculation. The basis for component footprinting is the application of lifecycle analysis to the production of consumables. This allows for a fuller picture of the impacts associated with material production and use as well as a meaningful distinction between primary (agricultural and mineral) and secondary (manufactured) products. The resultant footprint may therefore be more representative of a local area or organisation impact.

Simmons et al. (2001) argue that component footprinting should not be regarded as a perfect model or a replacement for compound footprinting, as both have advantages and disadvantages. Which method is adopted is dependent on available data and the purpose of the footprinting. Component methods allow detailed footprints that account for numerous products and practices but include a greater degree of uncertainty. Compound footprinting may result in a more robust overall value but do not reliably account for the disaggregated sub-components. In theory, if calculated correctly a compound footprint should contain all the information contained in the component footprint. It may be better to adopt the position that any footprint calculation exercise should not be based on either compound or component methods, but rather explore the possibility of applying the best elements of each method.

\section{Methodological issues common to both cities}

As with all studies of consumption, ecological footprint analysis faces boundary issues, in relation to what to include and exclude. A fundamental question faced was whether the study should calculate the Limerick and Belfast footprints within geographical (administrative) or responsibility boundaries (based on the consumption of an area's residents regardless of where it occurs). For the Limerick footprint, suburbs and satellite towns outside the administrative boundary were included. The Belfast footprint accounts only for consumption attributed to the city's population. Data availability was a common problem. In both Limerick and Belfast studies, local scale data were difficult to obtain for most categories. Estimates of Belfast per capita consumption were made by proxying either Belfast Metropolitan Area, Northem Ireland or UK sources. National resource use data were used to proxy Limerick per capita consumption. While these proxies may reflect activity in both cities, proxies are not as reliable as primary data, thus reducing the reliability of the footprints calculated.

If a footprint study is designed to meet academic criteria, then it will require high levels of detail in the methodology adopted. This will usually be accompanied by a more comprehensive disaggregating of consumption categories and will normally require the application of a bottom up model, or expansive conversion factors such as those applied by the UK based consultancy BestFootForward. If, on the other hand, the project is designed primarily for awareness raising purposes, then it probably will not require as great a level of methodological sophistication.

All footprint calculation exercises need to address the issue of trade-offs between rigour and clarity. Footprinting for informing policy may be seen as a tool which links academic research and the need for awareness raising, providing a metric that accounts for most human 
activities with environmental impacts but at the same time can be used as an aid for decision makers. Again this highlights that data availability is crucial in determining the method to be adopted. Obviously a more detailed component method is preferable but this is rarely possible given the large range of data required. Due to gaps in data availability, the methodology applied in the Limerick and Belfast calculations followed an aggregate model, incorporating elements from various methodologies. Both incorporated elements of compound and component footprinting to reflect data availability for each category.

\section{Footprinting methods}

The data used in the following footprint calculations were based on information from the year 2001 .

\section{Energy Footprinting for Limerick}

The calculation of Limerick's energy footprint is similar to that applied in the Belfast study. This method is compound in nature and based on the 2001 national energy oil balances available from government sources. These allowed for the trade corrected consumption of fossil fuels to be calculated. In order to convert to area figures, the national consumption values (in terms of tonnes of oil equivalent) were converted to units of energy. The International Energy Association (IEA, 2006) provided an energy conversion factor. Once energy consumption was converted to Kilojoules, the original conversion factors developed in Wackernagel and Rees (1996) were applied. In this way the area of forest required to absorb the carbon dioxide released by oil burning was calculated. In relation to renewable energy, conversion factors given by Simmons et al. (2001) were applied (see Table 2). National per capita values were calculated, which allowed estimation for Limerick on the basis that the greater city region supports 1.7 percent of the national population.

Table 2: Energy data for the Limerick Energy Footprint.

\begin{tabular}{cccccc}
\hline & $\begin{array}{c}\text { National } \\
\text { Consumption }\end{array}$ & $\begin{array}{c}\text { Conversion } \\
\text { Factor }\end{array}$ & $\begin{array}{c}\text { National } \\
\text { Footprint }\end{array}$ & $\begin{array}{c}\text { Limerick } \\
\text { Population }\end{array}$ & $\begin{array}{c}\text { Limerick } \\
\text { Footprint }\end{array}$ \\
\hline Unit & TOE*1000 & Gj/ha & Global ha & Proxy & Global ha \\
Coal & 2042 & 55 & 1547688 & $1.7 \%$ & 26310.69 \\
Peat & 885 & 55 & 670765.6 & $1.7 \%$ & 11403.02 \\
Oil & 8436 & 71 & 4974626 & $1.7 \%$ & 84568.65 \\
$\begin{array}{c}\text { Natural gas } \\
\text { Hydro }\end{array}$ & 3140 & 93 & 1413608 & $1.7 \%$ & 24031.33 \\
$\begin{array}{c}\text { Electric } \\
\text { Other }\end{array}$ & 51 & 1000 & 2125.9 & $1.7 \%$ & 36.1403 \\
Renewables & 208 & 9090 & 953.87 & $1.7 \%$ & 16.21579 \\
\hline
\end{tabular}

\section{Energy Footprinting for Belfast}

Belfast's direct energy is consumed at household level in the form of electricity, gas, coal, wood and fuel oil. Calculation of the ecological footprint of direct domestic energy consumption required an analysis of household consumption of electricity, coal and gas. $\mathrm{CO}_{2}$ 
emissions from the consumption of energy were converted into the footprint by considering the amount of land required to sequester the pollutant. Fuels produce different quantities of $\mathrm{CO}_{2}$ emissions per unit of energy produced. Conversion factors from DEFRA (2000) were used to calculate the $\mathrm{CO}_{2}$ emission associated with different energy sources (Table 3).

Table 3: Conversion of $\mathrm{CO}_{2}$ emissions into ecological footprint.

\begin{tabular}{lcrccc}
\hline Gas (GWh) & $\begin{array}{c}\text { GWP/GWh } \\
\text { (tCO }\end{array}$ & $\begin{array}{l}\text { Energy } \text { Yield } \\
\text { Land } \\
\text { (kg/ha) }\end{array}$ & $\begin{array}{l}\text { Direct } \\
\text { Factor }\end{array}$ & $\begin{array}{l}\text { Equiv. } \\
\text { Land }\end{array}$ & $\begin{array}{l}\text { Footprint } \\
\text { (ha/tonne gas) }\end{array}$ \\
Energy Land & 190 & 36.54 & & 1.78 & 64.96 \\
\hline
\end{tabular}

Source: Barrett et al. 2002.

Data on industrial energy use at local level were difficult to capture due to power supply companies' refusal to provide commercially sensitive data. Footprints for gas, oil and coal were calculated using national Department of Trade and Industry $\mathrm{CO}_{2}$ emissions data. Energy data were converted to the standard unit of Gigawatt hours (GWh). Data on GWh/capita for energy were then multiplied by the footprint per GWh to give a total ecological footprint for each fuel type.

\section{Transport footprinting for Limerick}

A component method was used to calculate the Limerick transport footprint. The method applied to car travel was identical to that used in the Belfast footprint, based on a method adopted in the York footprint study (Barrett et al. 2002) and was calculated using information from the National Roads Authority (NRA) National Roads and Traffic Flow report for 2001. Initially car kilometres of transportation through Limerick were calculated by multiplying the road length oy the average number of vehicles that travelled on it. The car values were segregated from the aggregated vehicle kilometre values, again provided by the NRA, which included vans, trucks and buses. The component for built land was calculated by multiplying the available road space by the NRA estimated percentage of daily vehicle kilometres undertaken by car, and the NRA also provided an occupancy estimate. The total car kilometres were multiplied by the area of land required to produce sufficient petrol and maintenance oil to allow a car to travel one kilometre. This has been termed the 'uplift factor' as it increases the transport footprint and was developed by Wackernagel and Rees (1996). The various factors were aggregated and multiplied by the vehicle kilometres to provide an overall value (see Table 4). Heavy good vehicle kilometres were calculated in the same manner, and the conversion factor adopted followed Simmons et al. (2001). Public transportation values were calculated by applying conversion factors developed by Simmons et al. (2001). These were then applied to passenger kilometre values (or tonnes kilometre in the case of rail freight) calculated using data provided by Bus Eireann and Irish Rail.

\section{Transport Footprinting for Belfast}

In order to obtain an ecological footprint for passenger transport in Belfast, an analysis of the main transport modes used by Belfast's residents was undertaken. Data for the number of passenger movements measured in kilometres travelled by air, car, bus, rail bike and motorcycle per annum were available and the impact of each mode was calculated through conversion factors derived using: 

1) fuel consumption estimates
2) energy and materials used in manufacture and maintenance of vehicles
3) passenger $/ \mathrm{km}$ journey data estimates
4) occupancy data and estimates, and
5) road length and average 'road shares' of vehicle types.

Table 4: Sample calculation of a car conversion factor (taken from Simmons et al., 2001).

\begin{tabular}{|c|c|c|c|c|}
\hline Component & Inputs & $\begin{array}{l}\mathrm{CO}_{2} \\
\text { Emission }\end{array}$ & $\begin{array}{l}\text { Built-upon } \\
\text { Land } \\
\end{array}$ & $\begin{array}{l}\text { Ecological } \\
\text { Footprint }\end{array}$ \\
\hline Petrol & $0.094 \mathrm{~L} / \mathrm{Km}$ & $0.22 \mathrm{~kg} / \mathrm{km}$ & & $\begin{array}{l}0.0000439 \\
\mathrm{ha} / \mathrm{car}-\mathrm{km}\end{array}$ \\
\hline $\begin{array}{l}\text { Maintenance } \\
\text { and Manufacture }\end{array}$ & $0.0423 \mathrm{~L} / \mathrm{Km}$ & $0.099 \mathrm{~kg} / \mathrm{km}$ & . & $\begin{array}{l}0.00001934 \\
\text { ha/car-km }\end{array}$ \\
\hline Road Space & & & 3,047 , ha & \\
\hline Car Road Share & $86 \%$ & & & \\
\hline Car Km's & $6,160,000,000$ & & & \\
\hline Car Occupancy & 1.6 person & & & \\
\hline Footprint & & & $\begin{array}{l}0.00000004 \\
\mathrm{ha} / \mathrm{car}-\mathrm{km}\end{array}$ & $\begin{array}{l}0.0000390 \\
\mathrm{ha} / \text { pass-km }\end{array}$ \\
\hline
\end{tabular}

Table 4 provides an example of how a footprint estimate was derived for a single passenger kilometre by car. The conversion factor used to calculate the footprint changes over time to reflect increases in the efficiency of engines and the amount of carbon dioxide emitted, especially from cars. Passenger kilometres (the number of kilometres travelled by passengers) for each mode were then multiplied by the footprint per kilometre to give the total footprint for that mode. The resulting footprints per mode were then summed. It proved difficult to attribute freight transport to the Belfast City area as many goods produced in Northern Ireland are exported and many items are freighted through Belfast to another destination. To estimate Belfast's freight transport footprint, the UK average (0.66gha per capita) was adopted (DRDNI, 2006) and then multiplied by the population of Belfast.

\section{Food Footprinting for Limerick}

The food footprint was calculated using the York study methodology (Barrett et al., 2002). Food footprinting was based on a combined compound and component method in which average national consumption data were used as proxies for Limerick data. The footprint calculation differed from that adopted by Wackernagel and Rees (1996) in that categories were subdivided. Average per capita Irish retail figures were available from the European Marketing Data 2002 report. These were then multiplied by the population of Limerick and converted using factors adopted in Barrett et al. (2002). The York Footprint used an energy analysis programme that was employed throughout the York Report to 
calculate the embodied energy of selected materials and the amount of carbon dioxide equivalent emissions resulting from the processing of manufactured goods (Barrett et al., 2002). In the absence of an available value for average Irish carbon sequestration, the Limerick study assumes that 5.2 tonnes of carbon dioxide will be absorbed by one hectare (Barrett et al., 2001). This energy land area is then converted into the equivalent number of hectares of land of global average productivity, assuming an average forest productivity of 1.78 times the global average (Barrett et al., 2002). Equivalence factors for each land category were employed to express the value as global average (see Table 5).

Table 5: Equivalence factors as used in Barrett et al. (2002).

\begin{tabular}{lc}
\hline Footprint areas & Equivalence Factors \\
\hline Absorbing area from fossil fuel & 1.77 \\
Infrastructure & 3.16 \\
Growing crops & 3.16 \\
Grazing animals & 0.39 \\
Producing wood & 1.78 \\
Harvesting fish/sea food & 0.062 \\
\hline
\end{tabular}

\section{Food footprinting for Belfast}

A similar method was adopted for Belfast: the average embodied energy for food was calculated by combining data on UK food consumption (DEFRA, 2000) with the embodied energy estimates used in the Living Planet Report spreadsheet. It was assumed that these relate only to food production, that is, the impacts of freight, packaging and preservation are excluded. The equivalence factors were derived from UK data and were used to equate Belfast's productivity to global productivity. They were then summed to give food and drink conversion factors (ha/tonne) for the various food and drink categories (Table 6). The total consumption of thirty two food and drink types was considered and for each was calculated a footprint per unit tonne. The National Food Survey was replaced by the Expenditure and Food Survey in 2001, which is subject to less under-reporting, and includes food and drink consumed outside the home (DEFRA, 2004). As Belfast specific data were unavailable, the consumption for each food and drink type per person for Northern Ireland was taken from the Expenditure and Food Survey, 2001. The tonnage of food for each product was then multiplied by the appropriate product conversion factor to give the total footprint, for that product. To avoid double counting food packaging was accounted for in the waste footprint while food transport was accounted for in the transport footprint.

\section{Waste Footprinting for Limerick}

As for food, the Limerick waste footprint was calculated using a combined method. Values for tonnes of waste arising in Limerick was supplied by Limerick City Council, the local authority. This was disaggregated using average waste composition percentages provided by the Irish EPA (EPA, 2002). As for food, the waste footprint calculates the embodied energy footprint (the forest area required to absorb the carbon emitted during production) along with waste kilometres, and the area occupied by the landfill. A method developed by the Intergovernmental Panel on Climate Change (IPCC, 1996), was used to 
calculate the footprint of methane production by determining the land required to absorb the landfill gas being produced by the break down of organic material. As less energy is required to convert waste into useable materials than is required to process virgin material, the recycling conversion factor is considerably lower.

Table 6: Samples of calculating conversion factors for biscuits.

\begin{tabular}{|c|c|c|c|c|c|c|}
\hline $\begin{array}{l}\text { Biscuits } \\
\text { (1 tonne) }\end{array}$ & $\begin{array}{c}\text { GWP/tonne } \\
\text { (tCO2 } \\
\text { equiv) }\end{array}$ & $\begin{array}{l}\text { Energy } \\
\text { land }\end{array}$ & $\begin{array}{l}\text { Yield } \\
\text { factor } \\
\text { (kg/ha) }\end{array}$ & $\begin{array}{l}\text { Direct } \\
\text { Land }\end{array}$ & $\begin{array}{l}\text { Equiv. } \\
\text { factor }\end{array}$ & $\begin{array}{c}\text { EF } \\
\mathrm{Ha} / \text { tonne }\end{array}$ \\
\hline $\begin{array}{l}\text { Energy } \\
\text { land }\end{array}$ & 2.72 & 0.52 & & & 1.78 & 0.93 \\
\hline $\begin{array}{l}\text { Crop land } \\
\text { Cereals }\end{array}$ & & & 5283 & 0.189 & 3.16 & 0.60 \\
\hline $\begin{array}{l}\text { Crop land } \\
\text { Sugar }\end{array}$ & & & 9687 & 0.103 & 3.16 & 0.33 \\
\hline $\begin{array}{l}\text { Crop land } \\
\text { Veg. oil }\end{array}$ & & & 2146 & 0.466 & 3.16 & 1.47 \\
\hline Total & & & & & & 3.33 \\
\hline
\end{tabular}

\section{Waste Footprinting for Belfast}

Calculation of the footprint for waste arising in Belfast proved challenging, and a number of assumptions were made. For household waste, the average tonnage per household was available and this was then multiplied by the number of households in Belfast (CSO, 2003). It was possible to determine the composition of household waste from the Belfast City Waste Composition analysis, published in the arc21 Waste Management Plan (2003). The conversion factors for each type of waste used in York (2002) were adapted and applied to estimate the footprint for household waste. The footprint for non-household wastes were proxies based on per capita values for Northern Ireland published in Northern Limits (2002). Only wastes that were not already included in other calculations were included to minimise double counting.

\section{Housing and Water Footprinting for Limerick}

As a value for construction material used per annum was not available, the number of houses granted planning permission was used as a proxy. This gave an estimate of the distribution of housing types as well as numbers. Barrett et al. (2002) provide conversion factors based on the average material composition of each house type, based on embodied energy estimates. What distinguishes this method is that the conversion factors are dispersed through the functional life of the house, assumed to be on average one hundred years, resulting in a cumulative footprint value. Unlike calculation of the Belfast footprint, Limerick footprinting did not take account of housing already present. The water footprint uses a conversion factor provided in Simmons et al. (2001), which incorporates the energy required to treat and pump water for municipal use. Limerick City Council provided data on annual water usage.

\section{Housing and Water Footprinting for Belfast}

The number of dwellings built in Belfast was obtained from the Northern Ireland Housing Statistics 2002-03 web site (DSD, 2003). The number of dwellings that were granted 
planning permission was used as an estimiate for the number of dwellings built. The proportion of each house type present in the city (bungalow, terraced, semi-detached, detached and apartment/flat) was applied to the number built to estimate the number of dwellings per type. The same conversion factors as those used in the Limerick footprint were applied. These factors assume that all dwellings are functional over 100 years (See Table 7). For housing already existing in Belfast, it was assumed that the hectares per capita value $(0.08$ gha) provided in the Northern Limits (2002) study was valid and this was then multiplied by the population of Belfast. The resultant value added to the value for new buildings quantified the total housing footprint. The water consumption footprint for Belfast was calculated using the hectares per capita $(0.01 \mathrm{gha})$ footprint for Northern Ireland as used in the above study. This footprint includes the energy required to collect, treat and supply water, and for wastewater treatment.

Table 7: Conversion factors for dwelling types (Barrett et al., 2002).

\begin{tabular}{lc}
\hline Dwelling Type & ha/dwelling \\
\hline Bungalow & 2.17 \\
Detached & 2.17 \\
Semi-detached & 2.17 \\
Terraced & 1.49 \\
Apartment & 1.65 \\
\hline
\end{tabular}

\section{Assumptions and limitations}

Similar difficulties were encountered and assumptions made in both studies, as a result of data gaps. A major assumption made in both studies was that national data represent acceptable proxies for city-specific data. The availability of data is often affected by whether services are provided publicly or by private companies; local scale data are often considered confidential by private companies. Compound footprinting has been extolled as less data intensive than component footprinting. However, both suffer from the same problem of data availability. Further assumptions were made in relation to conversion factors. The carbon sequestration rate provided by Barrett et al. (2002) assumes a homogenous spatial distribution of carbon sequestering forest types, and for that reason the global hectare is the metric used in both studies. Clearly this is not the case, due to the difference in extent and type of forests. It is further assumed that global footprints are sufficiently comparable to actual footprints to be meaningful in their own right, as opposed to merely allowing comparison with the global per capita average. As was demonstrated by Erb (2004), and others, varying assumptions in footprint calculations may result in the significantly different outcomes.

\section{Results}

Tables 8,9 , and 10 provide the total aggregated footprints for Limerick and Belfast city. In order to adjust for double counting, the energy component of food and transport was removed from the total product calculation. As information on the quantity of internationally traded packaging and waste was not available, the embodied energy of waste and recycled material was not removed from the overall footprint because only domestically produced embodied energy creates a problem of double counting. Also, all of the material waste generated in 2001 may not have been produced in that year, so that some of the embodied energy relates to the footprint of 2000 . 
Table 8: Distribution of Limerick footprint values.

\begin{tabular}{|c|c|c|c|c|}
\hline Component (gha) & Footprint & $\begin{array}{l}\text { Energy } \\
\text { land }\end{array}$ & $\begin{array}{l}\text { Adjusted } \\
\text { footprint }\end{array}$ & Per capita \\
\hline Municipal water & 1626 & & 1626 & 0.023804 \\
\hline Energy & 146366 & & 146366 & 2.142767 \\
\hline Car & 66430 & 22630 & 43800 & 0.641223 \\
\hline Heavy vehicles & 9309 & 9302 & 7 & 0.000102 \\
\hline Rail freight & 10348 & & 10348 & 0.151493 \\
\hline Passenger rail & 2871 & & 2871 & 0.042031 \\
\hline Passenger bus & 3704 & 3697 & 7 & 0.000102 \\
\hline Food & 158453 & 90566 & 67886 & 0.993837 \\
\hline Domestic waste & 78297 & & 78297 & 1.146251 \\
\hline Commercial waste & 78557 & . & 78557 & 1.150058 \\
\hline Recycled waste & 2360.8 & & 2360.8 & 0.034562 \\
\hline Housing & 1042 & & 1042 & 0.015255 \\
\hline Total & 559364 & 126195 & 433169 & 6.341502 \\
\hline times Limerick's area & \multicolumn{2}{|c|}{279.6817} & 216.34 & \\
\hline Per Capita & \multicolumn{2}{|c|}{8.18} & 6.34 & \\
\hline
\end{tabular}

For Limerick (Table 8), the combined footprint of waste and recycled material comprised the largest footprint component. Note that both commercial and domestic wastes have similar footprint values and the total waste and recycled material footprint was only marginally larger than the food footprint value. Further, if all the recyclable material within domestic and commercial housing waste were to be recycled, then the footprint value would be reduced by approximately 50 percent. The possible reduction of the footprint as a result of increasing recycling depends on the overall composition of waste, as some materials require more energy to recycle than others. One of the main objectives of footprinting is the examination of the often over-looked impact of processing of materials. While this requires detailed lifecycle analysis and hence incurs a high degree of uncertainty, it does serve to distinguish the main contributors to the overall footprint. For example, food kilometres were assumed to be a substantial component of agricultural food production, but footprint analyses suggest that the energy inherent in fertilisers creates a greater environmental impact. For Limerick, the overall adjusted per capita footprint is slightly more than six global hectares, which is similar to a value generated by BestFootForward for London.

The calculation for Belfast resulted in a larger per capita footprint (Table 9). This is most likely in part the result of differences between methods adopted to minimise double counting. In calculation of the Belfast footprint, an attempt was made to avoid double counting at the consumption data stage, whereas in the calculation of the Limerick footprint certain energy components were removed during calculation of the final footprint. Differences in data quantity and collection methods provide further evidence to suggest methodological issues affected the outcome. In addition, the difference between city footprints is related to energy, as the energy footprint for Belfast is one ha. greater (Table 10). This may be explained in part 
by differences in conversion factors adopted, but as these were expressed in global hectares for both cities, it is more likely to reflect the quantity of energy consumed or the differences in the fuels used such as gas or coal.

Table 9: Distribution of Belfast footprint values.

\begin{tabular}{lcc}
\hline Component & Footprint (gha) & (gha/cap) \\
Food & 385351 & 1.389197919 \\
Animal-based & 260112 & 0.937708866 \\
Plant-based & 125239 & 0.451489053 \\
Passenger transport & 167599 & 0.604197685 \\
Private & 134617 & 0.485296927 \\
Of which: & & \\
Bicycle & 11 & $3.96552 \mathrm{E}-05$ \\
Car & 134193 & 0.483768399 \\
Motorbike & 413 & 0.001488873 \\
$\sim$ Public & 32982 & 0.118900757 \\
Of which: & & \\
Bus & 6432 & 0.023187486 \\
Rail & 525 & 0.001892635 \\
Taxi & 2045 & 0.007372265 \\
Air & 23980 & 0.086448371 \\
Freight Transport & 167608 & 0.60423013 \\
Housing & 4335 & 0.01562776 \\
Energy & 931543 & 3.358230801 \\
Waste & 729011 & 2.628098965 \\
Of which: & & \\
Household waste & 351144 & 1.265881013 \\
Commercial waste & 377867 & 1.362217952 \\
Total Footprint & 2385447 & 8.5995 \\
times Belfast's area & 207.4273 & \\
\hline
\end{tabular}

Table 10: Comparison Between Limerick's per capita footprint and Belfast's.

\begin{tabular}{lcc}
\hline Component & Limerick (gha/cap) & Belfast (gha/cap) \\
Food & 0.9938 & 1.3892 \\
Transport & 0.8349 & 1.2084 \\
Energy & 2.1428 & 3.3582 \\
Waste & 2.3309 & 2.6281 \\
Housing & 0.0153 & 0.0156 \\
\hline Total & 6.3177 & 8.5995 \\
\hline
\end{tabular}




\section{Discussion}

\section{How should the footprinting results be interpreted?}

The Limerick and Belfast footprints show that it is possible to use existing methods to construct a footprint for a city, generally relying on national scale data. For the most part, the per capita footprints calculated in this way proved to be similar. It has been suggested that city footprinting is futile, as few local data were available and proxies are over-reliant on untested assumptions (Van den Bergh and Verbruggen, 1999). While a study based on proxies can never be as accurate as one based on local data, it will still demonstrate that cities are focal points of resource consumption, resulting in footprints approximately two hundred times their area. This should be considered in the context that many indicators included in the calculations quantify pollution and even the most conservative estimates place current Western personal consumption well beyond what can be sustained on a global basis. If the global population were to consume resources on a level comparable to Western states, an additional two planets would be required. This is demonstrated by the fact that most developed countries have a footprint of over six global hectares, or bio-productive hectares, per person; three times the global earth-share.

Footprint analysis de-emphasises the by-products of consumption and directs attention towards consumption itself. It is unsurprising that the energy embodied in both food and material production comprised such a large component of the Limerick footprint. The restricted use of renewable energy means that high levels of industrial processing, such as the production of manufactured electronics, are to be expected to result in large footprints within the Republic of Ireland, as the energy used in production is generated using fossil fuels. Any footprint model must be transparent in order to allow scrutiny of the mechanics of its conversion factors. For example a high footprint for a target city may be because it is sited in a region with naturally low soil fertility. The application of a fertilizer will increase the bioproductive yield and decrease the yield footprint, but the embodied energy footprint will increase greatly.

In relation to energy consumption, footprinting has come under significant criticism as it is based solely on forest sequestration (Herendeen, 2000). As the footprint calculates the bioproductive land required to sequester carbon dioxide emissions, substituting fossil energy sources with crops used in bio-diesel production, for example, may not reduce the footprint due to the extent of the agricultural area required. Hence only the saving potential, not the substitution potential, can be expressed. Also, this value changes as ecological succession advances. While a forest stores carbon during its growing lifetime, any tree will ultimately die and biological processes will eventually result in the sequestered carbon being released into the atmosphere. To maximise carbon sequestration a forest area should be planted with a fast growing species, which is harvested once growth has peaked. The area should be re-planted with a similar species and the harvested wood converted into products with a long use life such as furniture or construction wood. ' $\mathrm{Net} \mathrm{CO}_{2}$ uptake is overestimated; it saturates to zero as succession is completed, unless there is a scheme to harvest the wood and prevent it from decaying' (Herendeen, 2000:15). Future development of footprinting methodology will need to account for different carbon dioxide sequestration rates related to a number of habitats, and temporal changes associated with succession.

The transport footprint failed to account for travel to and from Limerick on tertiary roads, for which Irish data were not available. While this is unlikely to significantly influence the 
overall footprint value, it again highlights the fact that adoption of a more complex calculation procedure achieves little in the absence of appropriate data. Having said that, the Limerick footprint value for car transport is considered to be reliable as it is based on firm information derived at local scale, augmented by well-researched information from British sources. Since most of the vehicles driven in Ireland are also available in Britain, it is reasonable to assume that the fuel and maintenance values are roughly applicable to the Irish motorist, although it might be argued that the quality of road surfaces and higher incidence of vehicle accidents may affect the 'uplift factor'. For public transport, a conversion factor based on vehicle kilometres is more suitable then passenger $\mathrm{km}$ values, as the former often result in overly high values.

The Limerick waste footprint exemplifies various problems associated with sub-national component footprinting. Nearly all of Limerick's waste is trucked to a landfill at Gortnadroma, approximately $35 \mathrm{~km}$ from the city. While a value for total tonnage was available from Limerick City Council sources, an accurate value for waste $\mathrm{km}$ was impossible to obtain as a number of private waste disposal companies were involved and most trucks followed waste collection routes, which included both Limerick city and surrounding rural areas. The same is true for recycled material. As mentioned previously, the environmental impact of production is considerable and is increased by the distance most food is transported. An estimate for food $\mathrm{km}$ was impossible to obtain due in part to the large number of retail outlets. A generally accepted value for the material constituents of an average house type was not found. Using the method applied in the York footprint (assuming all houses share a common compositions) the footprint is spread out during the lifecycle of the house (Barrett et al., 2002). This is an interesting approach, but would be difficult to adapt for other types of resource use because of the generally faster rate of consumption.

Footprinting is essentially 'snapshot' and excludes consideration of secondary and cumulative effects of consumption. A further criticism of footprinting is that it assumes sustainable land use (Lewan \& Simmons, 2001). This can be addressed if the reduction in land yield over time is applied in footprint calculations. Finally, the water footprint was calculated using a predetermined conversion factor. Another approach would be to calculate the water-catchment land area. This is of course complicated by the fact that this is also included in energy and arable land footprints.

Energy constitutes the greatest difference in per capita footprint values between Limerick and Belfast. As the Limerick footprint of energy consumption was calculated using national data, comparison in essence is between Belfast and the Republic of Ireland. One possible reason for this difference is Belfast's industrial activity. Apart from its port, which handles over 60 percent of Northern Ireland's sea trade and more than 20 percent for the island in total, the city is also an industrial centre. However, the manufacturing sector has declined in the last decade, employing only 8.7 percent of the work force in 2001 (ERINI, 2005). While Limerick also has an industrial base, such as Dell Computers, the number of individuals employed in industrial and related sectors is considerably less, as data from the Northern Ireland Research and Statistics Agency (DETI, 2004) and 2002 Census (CSO, 2003) shows.

Bearing in mind that the energy footprint is proxied from national data, a comparison within national employment figures (CSO, 2003) shows that the manufacturing sector accounts for 244,203 employees, approximately 15 percent of the total work force of 1.6 million in the Republic. Therefore an alternative explanation for the difference in energy consumption may be required. 
Table 11: Comparison of employee numbers for selected sectors.

\begin{tabular}{lcc}
\hline Industry & Limerick 2002 & Belfast District 2003 \\
\hline $\begin{array}{l}\text { Mining, quarrying } \\
\text { and turf production }\end{array}$ & 20 & 86 \\
$\begin{array}{l}\text { Manufacturing Industries } \\
\text { Electricity, gas }\end{array}$ & 4,240 & 13,153 \\
and Water supply & 122 & 922 \\
\hline
\end{tabular}

Development in Belfast has not grown in recent years as quickly as Limerick and therefore contains a larger proportion of older houses built to lower insulation standards and therefore requiring more energy to heat. This suggestion is supported by evidence presented in the Northern Ireland House Condition Survey (1998) which shows that compared to Northern Ireland as a whole, houses in Belfast have a lower average energy efficiency. This is due in part to differences in house age and tenure systems. The problem is aggravated by the fact that thete is relatively high reliance on open-fire heating systems in Belfast, which are usually poorly energy efficient. Houses with a standard assessment procedure (SAP) energy rating of less than 20 are likely to cause 'fuel poverty' and consume excessive amounts of solid fuel: approximately 20 percent of houses in Belfast were in this category. The relatively recent arrival of natural gas in Northern Ireland in 1996 is in stark contrast to the Republic, which has used natural gas for several decades. The Department of Enterprise, Trade and Investment estimate that between 60-70 percent of home heating in Northern Ireland is oil fired (DETINI, 2006).

Transport is an important component of both footprints, with the per capita value for Limerick being slightly larger. Belfast contains an international airport, whereas Limerick is served by Shannon airport, which is located outside of the city. The Belfast transport footprint calculation included air transport while the Limerick calculation did not, and this in part explains the differences in values. The Limerick road traffic footprint method is based on the responsibility principle, whereby traffic on primary and secondary roads leading into and out of the city were included, along with bus and rail journeys. The method adopted for Belfast restricted the calculation to traffic within the city borders. Values suggest that the greater volume of car traffic using Limerick more than compensates for the lack of air transport. While individually the footprint of a single car kilometre is not great, large numbers of journeys cumulatively have an important impact. If extra-city road transport were to be incorporated into the calculation, the Belfast footprint may be expected to increase significantly as suburban expansion is a feature of the Belfast Metropolitan Area, with car transport the dominant transportation mode (McEldowney, Scott and Smyth, 2004). This 'out of town' and 'edge of town' growth in retail, leisure, commercial and residential capacity has developed along the main transport infrastructure, especially motorways and bypasses. Unless public transport services develop, then the road transport footprint is likely to become a larger component of the overall footprint.

Belfast has been identified as one of the United Kingdom's most car dependent regions. Recent provisions of urban infrastructure have served to provide increased incentives for private transport by car. This includes road quality, parking facilities, and the overall quality of the road network. Cinalli (2003) shows how the development of the West Link road coincided with an increase in car transport. This problem is of course two-fold. Cooper et al. 
(2001) demonstrate how significant areas of the city are not adequately supplied with accessible public transport services. This is likely to become more of an issue given the recent growth beyond the established urban centres. In addition to the apparent favour afforded to private transport Cooper et al. (2001) demonstrates the difficulties faced by any increase in the provision of public transport. Many of these can certainly be categorised as related to infrastructure, such as the aforementioned expansion and the increase of off road parking. In addition the socio-political instability associated with 'the troubles' has also served to hinder the development of efficient public transport. This effect was demonstrated by Boal (1969), who stated that territoriality is an important deciding factor in picking trip routes and this does not appear to have changed, despite recent political advances. Shirlow (2003:84) demonstrates how maximum utilisation of services is hampered.

Only $20 \%$ of those surveyed in Upper Ardoyne would use their closest facilities, all of which are located within Ardoyne. Similarly, only 18\% of Ardoyne respondents use the leisure centre in upper Ardoyne.

This is compounded by the perception that public transport does not provide adequate safety when compared with private transport. This has resulted in financial and logistical constraints that have caused increasing cutbacks by public transport operators (Cooper et al., 2001).

There may be a further explanation for Belfast's increased footprint. While both cities are large urban areas, Belfast is a much larger population centre. In essence comparing Belfast to Limerick is similar to comparing Limerick to Dublin. Belfast as a regional capital may be expected to have sufficient critical mass to attract people from a much larger hinterland than does Limerick. Cork City is both larger than, and relatively close to, Limerick and creates a counter attraction, which may be expected to limit the size of Limerick's hinterland. Recent sub-urbanisation beyond city boundaries is a dominant feature in Limerick and reliance on car transport is growing in part because alternatives are lacking or not considered safe.

It is difficult to account for the difference in food footprints. Simply stating that UK residents consume more food is not a satisfactory explanation. The difference may be explained by the use of budgetary data in calculating the Belfast footprint, and using tonnage data in calculating the Limerick footprint. It is more likely however that the larger footprint is due to the UK data accounting also for food eaten outside the home, whereas the Irish data do not.

Waste accounts for a considerable proportion of both footprints. In each case, low recycling levels and a reliance on landfills are coupled with a dependence on toxic waste treatment plants not located on the island of Ireland. Belfast creates much waste. For example, in 2002, the Belfast area produced 29 percent of the total in the Northern Ireland Industrial . and Commercial Waste Survey (EHS, 2002). The level of waste recycling is lower in Belfast than the average value for the Republic of Ireland (Collins et al., 2003) and this may explain the higher waste footprint there. However both values may be underestimates, as no information was available on the quantity of waste which is exported for international treatment, and the energy used in international transport may be expected to be significant.

\section{Why choose footprinting?}

Results reported here demonstrate an increase over time in consumption, but this is not a novel finding, as such increases are well documented using other measures. This begs the 
question 'what is the value of calculating these footprints?' The point has been made that collecting data to calculate footprints may foster greater cooperation and integration. But what are the advantages of using a sustainability indicator as opposed an environmental indicator? In order words what can the footprint of energy tell us that energy consumption or carbon emissions cannot? The main difference between an environmental indicator and a sustainability indicator is that the latter implies a certain limit or boundary. Inherent in footprinting is the assumption that there exists a baseline against which to compare current performance (Haberl et al., 2004). Adoption of the concept of 'the global earthshare' provides a coherent and quantitative measure of the extent to which we have achieved sustainability. Whereas an environmental indicator can give an estimate of the scale of resource use, a sustainability indicator can give an estimate on the extent to which this use rate is unsustainable. This difference is of value to policy makers as a footprint provides a single value to compare overall resource use over time and shows at a glance the extent to which an area, region or state is becoming more or less sustainable.

Footprinting has inherent difficulties. The main problem associated with footprinting is uncertainty. Often footprints are dependent on, or sensitive to, values that are in themselves estimates. For example, using a single yield value for a whole country is clearly an oversimplification. Unfortunately using a more disaggregated value can increase this uncertainty due to the high level of disagreement among embodied energy estimates. However it must be said that these uncertainties are common to many resource or energy accounting methods. Despite these inherent uncertainties footprinting remains a valuable tool. Firstly it allows straightforward comparisons amongst different regions and over time in the same region. Perhaps more importantly the footprint can be used to pose hypothetical questions and test the likely outcome of existing policies. For example a region may demonstrate a recent reduction in waste to landfill. However increasing private transport and energy consumption may outweigh any resultant footprint saving and thus contribute to an increasing footprint deficit when compared to the earthshare. This allows potentially vital policy areas to be distinguished from those that may not have as great an impact, and provides guidance as to where policy initiatives are most likely to deliver significant outcomes.

The footprint has been criticised for not fully representing the full concept of sustainable development as it fails to adequately take into account the social dimension. Undoubtedly human well-being is as vital to the Brundtland definition of sustainable development as is resource use and environmental resilience. This serves to highlight the need for the footprint to be viewed as only one of a suite of measures of sustainability. This can be especially important in urban areas where areas of consumption often coincide with areas of social dissatisfaction and disadvantage.

\section{Conclusions}

The footprints for the two cities provided a useful tool for the analysis of the sustainability of city metabolisms, and allow a comparative analysis of important footprint components. Monitoring progress towards sustainability requires a diverse indicator set, and the footprint can take its place within the growing set of sustainability indicators. The debate surrounding the relative advantages of component and compound footprinting is unlikely to be resolved in the near future. These two approaches to footprinting should not be considered as mutually exclusive, but rather as options to be employed as appropriate within a calculation. A combined method as applied in both the Limerick and Belfast footprints shows 
the advantage of including both in the situation where data are often difficult to obtain. Component based footprints rarely are calculated on the basis of new data, but rather they disaggregate into resource-use subsets data used in calculation of compound footprints. No footprint is fully inclusive of all categories and no footprint is ever truly completed. The growing complexity of the model is a testimony to the need to view footprinting as an iterative process.

\section{References}

ABEL, S., BRAUNSCHWEIG, A. and MÜLLER-WENK, R. (1990) Methodik für Ökobilanzen auf der Basis ökologischer Optimierung. Schriftenreihe Umwelt. Bern: Bundesamt für Umwelt, Wald und Landschaft.

BARRETT, J., VALLACK, H., JONES, A. and HAQ, G (2002) A Material Flow Analysis and Ecological Footprint of York, Technical Report. York: Stockholm Environmental Institute.

BELL, S. and MORSE, S. (1999) Sustainability Indicators. Measuring the immeasurable? London: Earthscan.

BOAL, F. W. (1969) Territoriality on the Shankill-Falls Divide, Belfast, Irish Geography, 6(2), 130-150.

BORGSTROM, G (1973) Harvesting the Earth. New York: Abelard Schuman.

CATTON, W. (1986) Carrying capacity and the limits to freedom. Paper prepared for Social Ecology Session 1, XI World Congress of Sociology. New Delhi, India.

COLLINS, C., MEANEY, B., NOLAN, K., MAHER, H. and CORISH C. (2003) Natonal Waste Database, Interim Report. Johnstown Castle Estate, county Wexford: Environmental Protection Agency.

COOPER, J., RYLEY, T., and SMYTH, A. (2001) Contemporary lifestyles and the implications for sustainable development policy: Lessons from the UK's Most Car Dependent City, Belfast, Cities, 18(2), 103-113.

CSO (CENTRAL STATISTICS OFFICE) (2003) Census 2002: Volume 5 - Principal Economic Status and Industries. Cork: CSO.

DETINI (DEPARTMENT OF ENTERPRISE, TRADE and INVESTMENT, NORTHERN IRELAND) Available at http://www.detini.gov.uk/cgi-bin/get_builder_page?page $=78 \&$ site $=5 \&$ parent $=77$

DRDNI (DEPARTMENT FOR REGIONAL DEVELOPMENT, NORTHERN IRELAND) Available at http://www.drdni.gov.uk/

DSD (DEPARTMENT FOR SOCIAL DEVELOPMENT) (1998) Northern Ireland House Condition Survey. Stormont: Statistics and Research Branch.

DSD (DEPARTMENT FOR SOCIAL DEVELOPMENT) (2003) Northern Ireland Housing Statistics. Stormont: Statistics and Research Branch. Available at http://www.dsdni.gov.uk/ni_housing_stats_ contents and intro.pdf

DSD (DEPARTMENT FOR SOCIAL DEVELOPMENT) (1998) Northern Ireland House Condition Survey. Stormont: Statistics and Research Branch.

DEUTSCH, L., JANSSON, A., TROELL, M., RONNBACK, P., FOLKE, C. and KAUTSKY, N. (2000) The "Ecological Footprint" - Communicating Human Dependence on Nature's Work, Ecological Economics, 32(3), 351-355.

DUCHIN, F. and LANGE, GM. (1994) The Future of the Environment: Ecological Economics and Technological Change. Oxford: Oxford University Press.

EPA (ENVIRONMENTAL PROTECTION AGENCY) (2002) Millennium Report. Johnstown Castle Estate, County Wexford, Ireland: EPA.

ERB, K. (2004) Actual land demand of Austria 1926-2000: a variation on Ecological Footprint Assessments, Land Use Policy, 21(2), 247-259.

ERINI (ECONOMIC RESEARCH INSTITUTE OF NORTHERN IRELAND) (2005) Manufacturing Matters: The Manufacturing Sector in Belfast: Decline or Renaissance? Belfast: Belfast City Council and ERINI.

ESH (ENVIRONMENT AND HERITAGE SERVICE) (2002) Industrial and Commercial Waste Production in Northern Ireland 2002. Belfast: EHS. 
GALLOPIN, G, HAMMOND, A., RASKIN, P. and SWART, R. (1997) Branch Points: Global Scenarios and Human Choice. PoleStar Series Report No.7. Stockholm: Stockholm Environmental Institute.

HABERL, H., WACKERNAGEL, M. and WRBKA, T. (2004) Land use and sustainability indicators. An introduction, Land Use Policy, 21(3), 193-198.

HAMILTON, C. (1999) The genuine progress indicator methodological developments and results from Australia, Ecological Economics, 30(1), 13-28.

HERENDEEN, R. A. (2000) Ecological footprint is a vivid indicator of indirect effects, Ecological Economics, 32(2), 357-358.

HOLDREN, J. and EHRLICH, P. (1974) Human Population and the Global Environment, American Scientist, 62(1), 282-292.

HOLMBERG, J., LUNDQVIST, U., ROBĖRT, K-H. and WACKERNAGEL, M. (1999) The Ecological Footprint from a Systems Perspective of Sustainability, International Journal of Sustainable Development and World Ecology, 6 (1): 17-33.

INTERGOVERNMENTAL PANEL ON CLIMATE CHANGE (1996) Revised 1996 IPCC Guidelines for National Greenhouse Gas Inventories. Available at http://www.ipccnggip.iges.or.jp/public/glinvsl.htm.

INTERNATIONAL ENERGY ASSOCIATION (2006). Available at http://www.iea.org

LAMBERT, J. (2005) A profile of rural Novia Scotia. Presented to the Nova Scotia Rural Team. Rural Secretariat, Atlantic Region

LENZEN, M. and MURRAY, S. (2001) A modified ecological footprint method and its application to Australia, Ecological Economics, 37(2), 229-255

LEWAN, L. and SIMMONS, C. (2001) The use of Ecological Footprint and Biocapacity Analyses as Sustainability Indicators for Subnational Geographical Areas: A Recommended Way Forward. Repcrt from Oslo Workshop 23-25th August 2001.

LOH, J. and WACKERNAGEL, M. (2002) WWF Living Planet Report 2002. Gland, Switzerland: World Wildlife Fund.

MCDONALD, G and PATTERSON, M. (2004) Ecological Footprints and interdependencies of New Zealand regions, Ecological Economics, 50(1), 49-67.

McELDOWNEY, M. (2001) Belfast Metropolitan case study. Queen's University, Belfast: School of planning.

McELDOWNEY, M., SCOTT, M. and SMYTH, A. (2003) Integrating land-use planning and transportation-policy formulation in the Belfast Metropolitan Area, Irish Geography, 36 (2), 112-126.

McGRANAHAN, G and SATTERTHWAITE, D. (2003) Urban Centers: An Assessment of Sustainability, Annual Review of Environmental Resources, 28(2), 243-274

MEADOWS, D., MEADOWS, D., RANDERS, J. and BEHRENS, W. (1972) Limits to Growth. New York: Universe Books.

NATIONAL ROADS AUTHORITY (2001) National Roads and Traffic Flow report. Available at http:/www.nra.ie/PublicationsResources/DownloadableDocumentation/Transportation/file,1162,e n.PDF

NORTHERN IRELAND STATISTICS AND RESEARCH AGENCY (2004) Northern Ireland Census of Employment, September 2003, District Council Areas by Section. Belfast: NISRA.

NORTHERN IRELAND STATISTICS AND RESEARCH AGENCY, DEPARTMENT OF ENTERPRISE, TRADE AND INVESTMENT (2004) Northern limits: a resource flow analysis and ecological footprint for Northern Ireland. Belfast and Oxford: Envirocentre and BestFootForward.

ODUM, H.T. (1994) Ecological and General Systems. Boulder: University of Colorado Press.

PIMENTEL, D., HERDENDORF, M., EISENFELD, S., OLANDER, L., CARROQUNNO, M., CORSON, C., MCDADE, J., CHUNG, Y., CANNON, W., ROBERTS, J., BLUMAN, L. and GREGG, J. (1994) Achieving a Secure Energy Future: Environmental and Economic Consequences, Ecological Economics, 9(2), 201-219. 
REES, W. (1994) Revisiting Carrying Capacity: Area-Based Indicators of Sustainability. Workshop on 'Evaluation Criteria for a Sustainable Economy', Institut fur Verfahrenstechnik, Technische Universitat Graz, Graz, Austria, (6-7 April, 1994)

SCHMIDT-BLEEK, P. (1994) Wieviel Umwelt braucht der Mensch? Birkhäuser. Basel: Verlag.

SHIRLOW, P. (2003) 'Who Fears to Speak': Fear, Mobility, and Ethno-sectarianism in the Two 'Ardoynes', The Global Review of Ethnopolitics, 3(1), 76-91.

SIMMONS, C. et al. (2000) Two feet - two approaches: a component-based model of ecological footprinting, Ecological Economics, 32 (3), 375-380.

SIMMONS, C., WACKERNAGEL, M.. and CHAMBERS, N. (2001) Sharing Nature's Interest. London: Earthscan.

STÖGLEHNER, G (2002) Ecological footprint -- a tool for assessing sustainable energy supplies, Journal of Cleaner Production, 11(2), 267-277.

UNITED NATIONS WORLD COMMISSION ON ENVIRONMENT AND DEVELOPMENT (1987) Our Common Future (The Brundtland Report). Oxford: Oxford University Press,.

VAN DEN BERGH, J. and VERBRUGGEN, M. (1999) Spatial sustainability, trade and indicators: an evaluation of the "ecological footprint", Ecological Economics, 29(1), 61-72.

VICTOR, P.A. (1994) Natural capital, substitution and indicators of sustainable development. Presentation at the 3rd Meet. ISEE, Costa Rica, Journal of Public Economics, 86(3), 341-360.

WACKERNAGEL, M., and REES, W. (1996) Our Ecological Footprint: Reducing Human Impact Upon the Earth. Canada: New Society Publishers.

WACKERNAGEL, M. and REES, W. (1996a) Urban ecological footprints: why cities cannot be sustainable--and why they are a key to sustainability, Environmental Impact Assessment Review, 16(46), 223-248.

WACKERNAGEL, M., LEWAN, L., FOLKE, C. and HANSSON, C. (1998) Evaluating the Sustuinability of a Catchment Area: The Ecological Footprint Concept Applied to Malmöhus County and the Kävlinge Watershed, Southern Sweden. Sweden: Lund University.

WACKERNAGEL, M. et al. (1999) National capital accounting with the ecological footprint concept. Ecological Economics, 29(3) 375-390. 